\section{No high Tibetan Plateau until the Neogene}

\author{
T. Su ${ }^{1,2 *}$, A. Farnsworth ${ }^{3}$, R. A. Spicer ${ }^{1,4}$, J. Huang ${ }^{1}$, F.-X. Wu ${ }^{5}$, J. Liu ${ }^{1}$, S.-F. Li ${ }^{1}$, Y.-W. Xing ${ }^{1}$, \\ Y.-J. Huang ${ }^{6}$, W.-Y.-D. Deng ${ }^{1,2}$, H. Tang ${ }^{1,2}$, C.-L. Xu ${ }^{1,2}$, F. Zhao ${ }^{1,2}$, G. Srivastava ${ }^{7}$, P. J. Valdes ${ }^{3}$, \\ T. Deng ${ }^{5}$, Z.-K. Zhou ${ }^{1,6 *}$
}

The Late Paleogene surface height and paleoenvironment for the core area of the Qinghai-Tibetan Plateau (QTP) remain critically unresolved. Here, we report the discovery of the youngest well-preserved fossil palm leaves from Tibet. They were recovered from the Late Paleogene (Chattian), ca. $25.5 \pm 0.5$ million years, paleolake sediments within the Lunpola Basin $\left(32.033^{\circ} \mathrm{N}, 89.767^{\circ} \mathrm{E}\right)$, central QTP at a present elevation of $4655 \mathrm{~m}$. The anatomy of palms renders them intrinsically susceptible to freezing, imposing upper bounds on their latitudinal and altitudinal distribution. Combined with model-determined paleoterrestrial lapse rates, this shows that a high plateau cannot have existed in the core of Tibet in the Paleogene. Instead, a deep paleovalley, whose floor was $<2.3 \mathrm{~km}$ above mean sea level bounded by ( $>4 \mathrm{~km}$ ) high mountain systems, formed a topographically highly varied landscape. This finding challenges prevailing views on tectonic processes, monsoon dynamics, and the evolution of Asian biodiversity.
Copyright $\odot 2019$

The Authors, some rights reserved; exclusive licensee American Association for the Advancement of Science. No claim to original U.S. Government Works. Distributed under a Creative Commons Attribution NonCommercial License 4.0 (CC BY-NC).

\section{INTRODUCTION}

The collision between the Indian and Eurasian plates changed the topography of southern Asia and led to the reshaping of regional and even global atmospheric circulation and climate $(1,2)$. However, the topographic evolution and paleoclimate history of the QinghaiTibetan Plateau (QTP) before and soon after the collision is very poorly constrained (3-7).

The Lunpola Basin is a large Cenozoic sedimentary basin on the QTP and is situated in the Bangong-Nujiang suture zone formed by the Mesozoic collision of the Lhasa and Qiangtang blocks (Fig. 1) $(8,9)$. The basin has been the focus of several paleoaltimetric studies $(3,5-7,10,11)$ because it offers considerable potential for understanding Tibetan landscape evolution and testing geodynamic models of the QTP formation. The Paleogene Lunpola sediment depocenter is located between the paleo-Gangdese (Eocene elevation, $4.5 \mathrm{~km}$ ) (12) and the paleo-Qiangtang (Tangulha) mountain ranges (Middle Oligocene elevation, $>5.0 \mathrm{~km})(13)$ to the south and north of the basin, respectively. Unexpectedly, Late Paleogene paleoelevation estimates for this core of Tibet diverge by as much as $4000 \mathrm{~m}$, with some isotope studies suggesting a high (4 to $5 \mathrm{~km}$ ) Lunpola Basin floor $(3,7)$, while paleontological data point to much lower elevations of between $\sim 1$ and $\sim 3 \mathrm{~km}(4-6,11)$.

Stable isotope quantitative paleoaltimetric proxies are widely used but rely heavily on assumptions regarding the composition of moisture sources, spatially and temporally varying isotopic lapse rates, evapotranspiration, and air parcel trajectories that can change seasonally (14-16). Isotope paleoaltimetry works best where prevailing winds rise normal to a single mountain ridge and where Rayleigh distillation occurs, whereas evaporation/precipitation recycling over plateaus or multiple mountain ranges generates large, poorly quantifiable, uncertainties (17).

Similarly, fossil-based paleoelevations based on organismal temperature constraints and thermal lapse rates can be unreliable because

\footnotetext{
${ }^{1}$ Key Laboratory of Tropical Forest Ecology, Xishuangbanna Tropical Botanical Garden, Chinese Academy of Sciences, Mengla 666303, China. ${ }^{2}$ University of Chinese Academy of Sciences, Beijing 100049, China. ${ }^{3}$ School of Geographical Sciences, University of Bristol, Bristol BS81SS, UK. ${ }^{4}$ School of Environment, Earth and Ecosystem Sciences, The Open University, Milton Keynes MK76AA, UK. ${ }^{5}$ Key Laboratory of Vertebrate Evolution and Human Origins, Institute of Vertebrate Paleontology and Paleoanthropology, Chinese Academy of Sciences, Beijing 100044, China. ${ }^{6}$ Key Laboratory for Plant Diversity and Biogeography of East Asia, Kunming Institute of Botany, Chinese Academy of Sciences, Kunming 650204, China. 'Birbal Sahni Institute of Palaeosciences, 53 University Road, Lucknow 226 007, India.

*Corresponding author. Email: sutao@xtbg.org.cn (T.S.); zhouzk@xtbg.ac.cn (Z.-K.Z.)
}

these lapse rates are highly variable in time and space (18), requiring prior knowledge of the topography under investigation. Moreover, all previous fossil-based surface height estimates for the core area of the QTP have used global (4) or regional (5) free-air thermal lapse rates instead of the more appropriate local paleoterrestrial thermal lapse rates (19), which incorporate the surface processes that strongly influence surface temperatures and land-atmosphere energy fluxes.

Plant megafossils are important indicators for paleoenvironmental reconstruction because their morphologies and spatial distributions are environmentally restricted and are seldom preserved far from their growth site (20). However, they are rarely recovered from the QTP because of logistical constraints. Here, we describe newly discovered palm fossil (Fig. 2 and fig. S1) leaves from the Lunpola Basin. The leaves are $\sim 1 \mathrm{~m}$ in length, with leaf blades radiating from the distal ends of $\sim 70$-cm-long petioles. Because the unique anatomical and physiological features of palms render them inherently frost sensitive (21), we can constrain quantitatively, with confidence, the maximum possible elevation of the floor of the Lunpola Basin at the end of the Paleogene and before the rise of Himalaya (22). To do this, we determine paleotemperatures at sea level using coeval proxy data, and, combined with climate model-generated local terrestrial thermal paleo-lapse rates for a range of topographic scenarios, paleoelevations are estimated using the coldest month mean temperature (CMMT) and the following expression

$$
Z=\left(T_{\mathrm{msl}}-T_{\mathrm{h}}\right) / \gamma
$$

where $Z$ is the elevation, $T_{\text {msl }}$ is the CMMT at mean sea level, $T_{\mathrm{h}}$ is the CMMT at elevation, and $\gamma$ is the local terrestrial thermal (CMMT) lapse rate (19).

\section{RESULTS}

\section{Fossil material and geological context}

Palms (family Arecaceae) are diverse with ca. 2585 living species and ca. 188 extant genera. Today, they are all restricted to tropical and subtropical regions and are important environmental indicators because in natural populations, they are highly susceptible to freezing, particularly as seedlings (21). Moreover, the thermophilic requirements of palms have remained relatively stable throughout the Cenozoic $(23,24)$. 

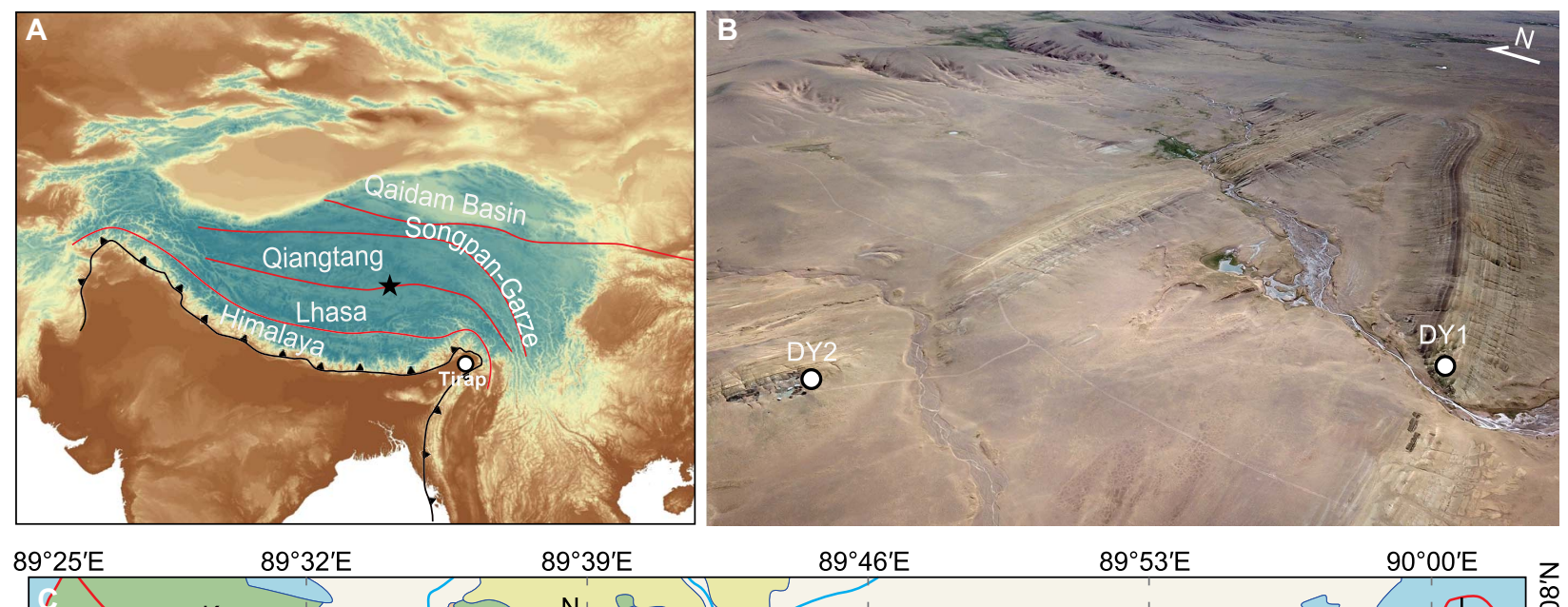

\section{as46e}

BSSSE

$90^{\circ} 00^{\prime} \mathrm{E}$

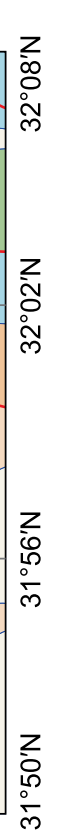

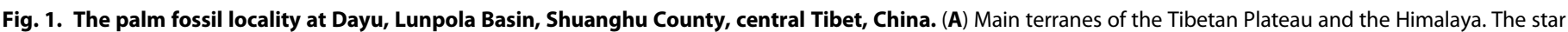

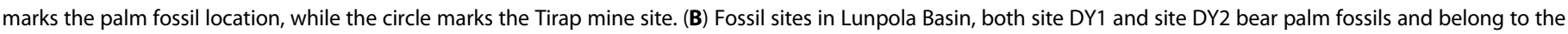

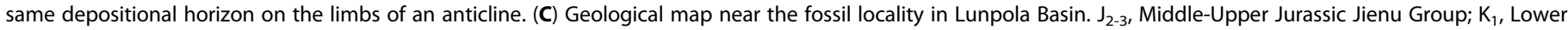

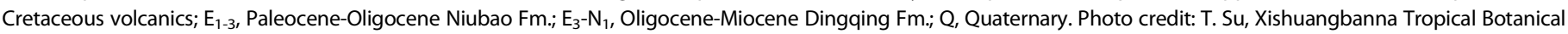
Garden (XTBG), Chinese Academy of Sciences (CAS).

Newly discovered well-preserved fossil palm leaves, here assigned to a new species Sabalites tibetensis T. Su et Z.K. Zhou sp. nov. (Fig. 2), occur in the Lunpola Basin $\left(32.033^{\circ} \mathrm{N}, 89.767^{\circ} \mathrm{E}\right)$ within Late Paleogene lake sediments of the lower Dingqing Formation. Ground and drone surveys locate this horizon $\sim 120 \mathrm{~m}$ below a U-Pb dated bentonite [23.6 \pm 0.2 million years (Ma)] (Fig. 1 and fig. S2) (10). Magnetostratigraphic constraints (5) point to the palm layer forming at $\sim 25.5 \pm 0.5 \mathrm{Ma}$ (Chattian). This finding, coupled with well-constrained paleoterrestrial lapse rates, allows us to quantify with a high degree of certainty the Late Oligocene elevation of the basin floor.

Numerous palm fossils have been reported worldwide (table S1), and fossils in this study can be assigned to the subfamily Coryphoideae, which, although it includes the most cold-tolerant tribe Trachycarpeae, also encompasses the tribe Sabaleae. Sabaleae contains genera to which Sabalites, in having costapalmate leaves (25), are most similar. Fossils from the Lunpola Basin are characterized by their prominent spine-like structures at the bases of the leaf blades (Fig. 2 and table S2), which are different from any other previously reported palm fossils.

S. tibetensis is morphologically most similar to living palms that belong to the tribe Sabaleae, which can tolerate CMMTs no lower than $5.2^{\circ} \mathrm{C}(21)$, while our own survey of the morphologically closest extant relatives suggests that $S$. tibetensis may not have tolerated a CMMT lower than $7.7^{\circ} \mathrm{C}$ and a mean annual temperature (MAT) below $14.2^{\circ} \mathrm{C}$ (table S3). However, MAT is not a meaningful measure of cold tolerance because any given MAT can reflect a wide range of growth-limiting thermal extremes, depending on the annual thermal range. Most critical is the lowest temperature reached and the duration of freezing encapsulated as the CMMT and the frequency of freezing conditions. For a conservative approach that yields the highest possible paleoelevations of the Lunpola Basin floor, we use the lowest CMMT that can be tolerated by all living palms $\left(5.2^{\circ} \mathrm{C}\right)(21)$, rather than that of the morphologically nearest living genera $\left(7.7^{\circ} \mathrm{C}\right)$. 


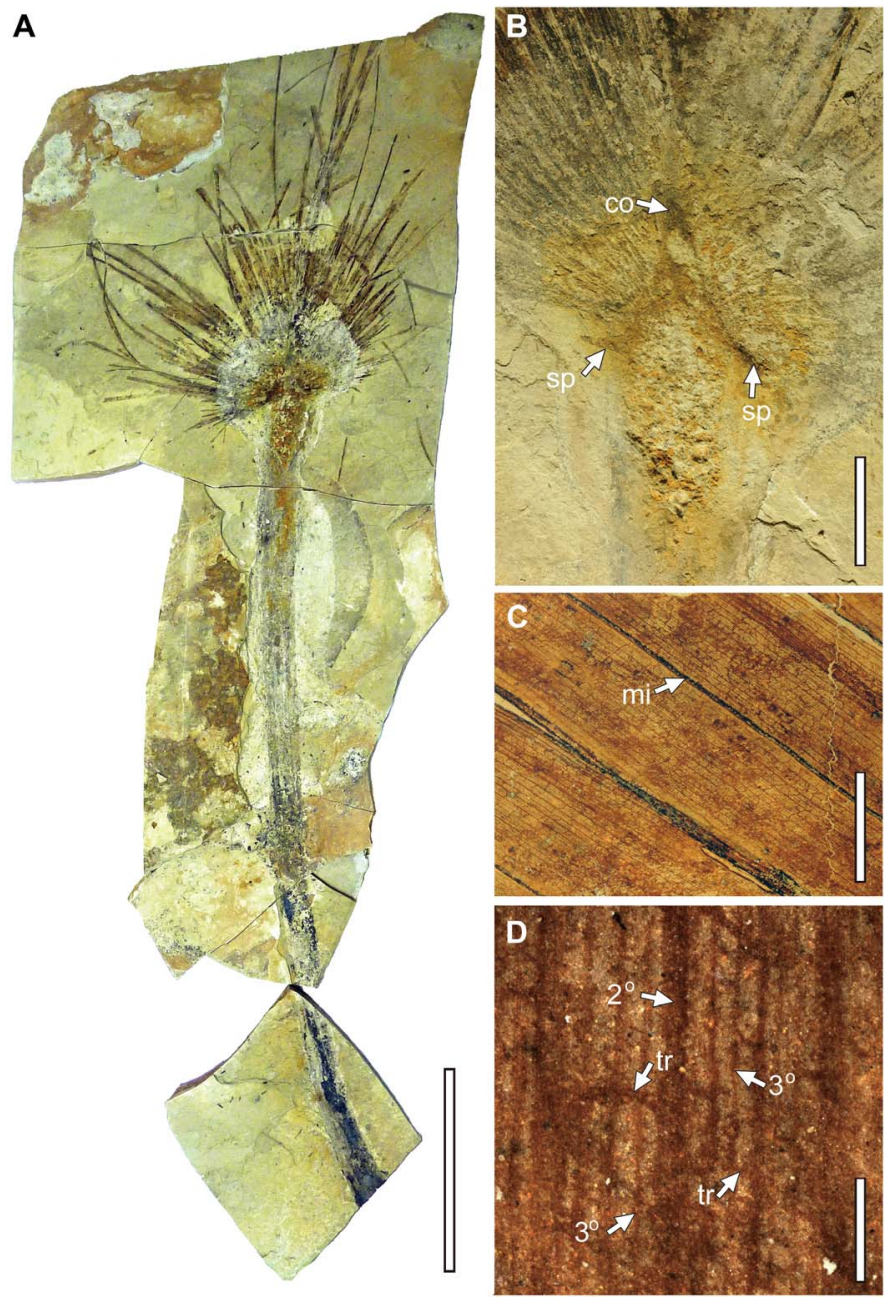

Fig. 2. S. tibetensis T. Su et Z.K. Zhou sp. nov. (A) Holotype, specimen no XZDY2-0200. (B) Enlargement of the basal part of leaf blade. co, costa; sp, spine-like structures. (C and D) Specimen no. XZDY1-0071, venation pattern. mi, mid-vein; $2^{\circ}$, secondary vein; $3^{\circ}$, tertiary vein; tr, transverse vein. Scale bars, $10 \mathrm{~cm}(A), 3 \mathrm{~cm}(B)$, $1 \mathrm{~cm}(\mathrm{C})$, and $1 \mathrm{~cm}(\mathrm{D})$. Photo credit: T. Su, XTBG, CAS.

To obtain the maximum paleoelevation at which S. tibetensis could have grown requires knowledge of paleothermal lapse rates at the growth location and the temperature regime at sea level at that location. Past attempts to quantify paleosurface height using this approach have used global (4) or regional (5) free-air thermal lapse rates, but these are highly variable in time and space, particularly inland, over plateaus and in mountainous landscapes (18). Moreover, free-air thermal lapse rates are very different from those that plants experience within a few meters of the land surface (terrestrial thermal lapse rates) (18) and are therefore inappropriate for phytopaleoaltimetry (19). Because terrestrial lapse rates are highly dependent on local climate and, thus, topography, justifying any particular lapse rate for Tibetan paleolocations without integrating climate modeling is problematic and unconstrained.

\section{Experimental design}

To determine surface paleoelevation from our palm fossils, we modeled Late Paleogene local terrestrial thermal lapse rates (LTTLRs) at the Lunpola paleolocation $\left(31.73^{\circ} \mathrm{N}, 83.11^{\circ} \mathrm{E}\right)$ using the HadCM3L (specifically HadCM3LB-M2.1) General Circulation Model, a version of the U.K. Met Office HadCM3 v. 4.5 family (26) with a resolution of $3.75^{\circ} \times 2.5^{\circ}$ longitude $\times$ latitude for both atmosphere and ocean.

Thirteen topographic sensitivity studies (scenarios V1 to V8 and P0 to P4) for Tibet were performed (fig. S3). Scenarios V1, V3, V5, and V7 comprise a topographic valley system where a Gangdese mountain range is set to $4.5 \mathrm{~km}$, the Qiangtang mountain range is set to $4 \mathrm{~km}$, and a valley floor height of $2 \mathrm{~km}$ is set between them. Scenarios V2, V4, V6, and V8 comprise a 3.3-km valley floor between the Gangdese and Qiangtang mountain system, each set to $4 \mathrm{~km}$. Because the paleorotated proxy site $\left(31.73^{\circ} \mathrm{N}, 83.11^{\circ} \mathrm{E}\right)$ is located on the boundary between two model grid cells, each valley topographic configuration was run for two model latitudinal locations: $32.5^{\circ} \mathrm{N}$ (V1 to V4) and $30.0^{\circ} \mathrm{N}$ (V5 to V8). These valley systems were further modified by opening (V1, V2, V5, and V6) and closing the eastern end of the valley into Yunnan (V3, V4, V7, and V8) based on recent data showing an elevated eastern Tibet at $33 \mathrm{Ma}$ (27). Scenarios P0 to P4 represent Tibet as a series of simple plateaus at elevations of 0 to $4 \mathrm{~km}$, respectively, with no mountain ranges.

Because $p \mathrm{CO}_{2}$ is uncertain for the Late Paleogene, with proxy estimates ranging from 280 parts per million (ppm) to as high as $1120 \mathrm{ppm}$ (although likely not $>840 \mathrm{ppm}$ ) (28), we also performed two $\mathrm{CO}_{2}$ sensitivity studies to assess the influence of $\mathrm{CO}_{2}$ on lapse rates. Our modeling automatically accounts for secular climate change. The Lunpola Late Paleogene LTTLRs vary, depending on topography ranging from $4.1^{\circ}$ to $7.64^{\circ} \mathrm{C} / \mathrm{km}$ (Table 1$)$, but doubling $\mathrm{CO}_{2}$ made a little difference $\left(+0.1^{\circ} \pm\right.$ $\left.0.159^{\circ} \mathrm{C} / \mathrm{km}\right)$. These LTTLRs differed markedly from the Late Paleogene global average terrestrial lapse rates $\left(4.61^{\circ}\right.$ to $\left.4.73^{\circ} \mathrm{C} / \mathrm{km}\right)$.

An essential component of the surface paleoelevation estimates using thermal lapse rates is knowledge of terrestrial temperatures at mean sea level $\left(T_{\mathrm{msl}}\right)$ proximal to the location whose elevation is being sought. Model-derived $T_{\mathrm{msl}}$ values are topographically dependent (Table 1), so here, we use real-world proxy data to estimate conservative (warm) $T_{\mathrm{msl}}$ values for the Lunpola site. The closest coeval terrestrial proxy data is a Climate-Leaf Analysis Multivariate Program (CLAMP)derived CMMT of $20.4^{\circ} \pm 3.6^{\circ} \mathrm{C}$ from Tirap, Assam, Northeast India $\left(27.289^{\circ} \mathrm{N}, 95.771^{\circ} \mathrm{E}\right)(29)$. Inconsistencies between proxy temperatures at Tirap (MAT and CMMT) and model predictions for that location highlight poorly performing model scenarios (Table 1).

The use of the lowest CMMT threshold for most extant palms $\left(5.2^{\circ} \mathrm{C}\right)$ and the Late Paleogene local LTTLR at the palm locality shows in all but two scenarios (V5 and V7) that the fossil palm could not have lived higher than $\sim 2.3 \mathrm{~km}$ above sea level (Table 1 ). This elevation bound rises by only $400 \mathrm{~m}$ if we use the CMMT threshold $\left(2.2^{\circ} \mathrm{C}\right)$ of the most cold-tolerant extant palms belonging to the Trachycarpeae, to which our fossil material shows only superficial resemblance and to which it is unlikely to be related.

Scenarios V1 to V4 all fail because the predicted CMMTs are too low at the prescribed land surface, as do scenarios V2, V4, V6, and V8, which also fail because the maximum survivable elevation $(\sim 2.1 \mathrm{~km})$ is below the model land surface $(3.2 \mathrm{~km})$. Model failure to reproduce the Tirap proxy conditions contributes to the failure of scenarios V2 and V6.

All plateau scenarios fail because either the CMMT is below the minimum $5.2^{\circ} \mathrm{C}$ for palm survivorship (P3 and $\mathrm{P} 4$ ), the predicted MAT at the Tirap site does not match the proxy data (P0 to P2), or the maximum elevation for palm survivorship is below the prescribed land surface (P3 and $\mathrm{P} 4)$.

The only scenarios compatible with both the sea level proxy constraint and palm survivorship above model land surface elevation are 
Table 1. Model-predicted climate and maximum survivable paleoelevations for an array of topographic scenarios (V1 to V8 and P0 to P4) for Tibet in the Late Paleogene. Thermal regimes regarded as fatal to palms (21) or failing to reproduce proxy values or occurring below prescribed land surfaces are shown in red. Blue shading indicates unconstrained (by proxy data) model-predicted CMMTs fatal to palms, and gray shading indicates model failure to reproduce proxy thermal conditions. Green shading indicates palm-survivable scenarios. The total number of frost days, number of 5-day cold events $<0^{\circ} \mathrm{C}$, and number of 5-day cold events $<-5^{\circ} \mathrm{C}$ during a 30-year period are shown. These indicate that above $2 \mathrm{~km}$, the frequency of potentially fatal frost periods increases markedly. The highest survivable paleoelevations of the palm fossil locality are based on the model-derived cold month mean temperature terrestrial lapse rate $\gamma$, a conservative proxy-based CMMT at mean sea level $T_{\text {msl }}$ obtained from the Tirap site $\left(20.4^{\circ} \mathrm{C}\right)$ using the PhysgAsia2 and HiResGridMetAsia2 calibration (47) and a minimum palm-survivable CMMT of $5.2^{\circ} \mathrm{C}$. Note that because Tirap is to the south of Lunpola, and Lunpola is not coastal, the theoretical CMMT at the Lunpola site may have been slightly cooler than this value. Asterisk (*) values indicate elevations lower than the prescribed land surface, indicating that no palm could live on that surface. Because of the uncertainty in paleopositioning of the Lunpola Basin, we ran a latitude sensitivity test (scenarios V5 to V8) where the location of the valley topography was moved one grid cell to the south. None of the plateau scenarios (P0 to P4) produce survivable conditions. The most plausible scenarios (green fill) are those consisting of a deep valley system with the valley floor set at $2 \mathrm{~km}$ above mean sea level (AMSL) at paleolatitude $\sim 30^{\circ} \mathrm{N}$ bounded by high (at least $4 \mathrm{~km}$ ) mountain systems.

\begin{tabular}{|c|c|c|c|c|c|c|c|c|c|c|}
\hline \multicolumn{2}{|c|}{$\begin{array}{l}\text { Topography } \\
\text { scenario }\end{array}$} & \multirow{2}{*}{$\begin{array}{l}\begin{array}{c}\text { MAT } \\
\left({ }^{\circ} \mathrm{C}\right)\end{array} \\
22.4\end{array}$} & \multirow{2}{*}{$\begin{array}{c}\begin{array}{c}\text { CMMT } \\
\left({ }^{\circ} \mathrm{C}\right)\end{array} \\
4.0\end{array}$} & \multirow{2}{*}{$\begin{array}{c}\begin{array}{c}\text { Total frost } \\
\text { days }\left(<0^{\circ} \mathrm{C}\right)\end{array} \\
2504\end{array}$} & \multirow{2}{*}{$\begin{array}{c}\begin{array}{c}\text { No. 5-day } \\
\text { events } \\
<0^{\circ} \mathrm{C}\end{array} \\
161\end{array}$} & \multirow{2}{*}{$\begin{array}{c}\begin{array}{c}\text { No. 5-day } \\
\text { events } \\
<-5^{\circ} \mathrm{C}\end{array} \\
68\end{array}$} & \multirow{2}{*}{ 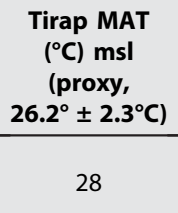 } & \multirow{2}{*}{ 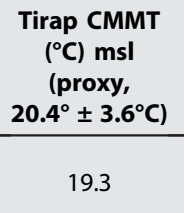 } & \multirow{2}{*}{$\begin{array}{c}\begin{array}{c}\text { Lunpola } \\
\text { CMMT }\end{array} \\
\text { lapse rate } \\
(\gamma)\left({ }^{\circ} \mathrm{C} / \mathbf{k m}\right)\end{array}$} & \multirow{2}{*}{$\begin{array}{c}\begin{array}{c}\text { Predicted } \\
\text { highest } \\
\text { survivable } \\
\text { elevation (m) }\end{array} \\
2867\end{array}$} \\
\hline V1 & $\begin{array}{l}\text { Valley }(2 \mathrm{~km}), 4 \mathrm{~km} \\
\text { uplands, open }\end{array}$ & & & & & & & & & \\
\hline V2 & $\begin{array}{l}\text { Valley }(3.2 \mathrm{~km}), 4 \mathrm{~km} \\
\text { uplands, open }\end{array}$ & 15.9 & 0.4 & 3662 & 165 & 140 & 26.5 & 16.6 & 7.1 & $2132^{*}$ \\
\hline V3 & $\begin{array}{l}\text { Valley }(2 \mathrm{~km}), 4 \mathrm{~km} \\
\text { uplands, } \\
\text { closed }\end{array}$ & 21.2 & 1.2 & 2854 & 160 & 91 & 27.8 & 19.1 & 4.1 & 3719 \\
\hline V4 & $\begin{array}{l}\text { Valley }(3.2 \mathrm{~km}), 4 \mathrm{~km} \\
\text { uplands, closed }\end{array}$ & 16.3 & 0.1 & 3695 & 185 & 146 & 27.8 & 19.1 & 6.8 & $2233^{*}$ \\
\hline V5 & V1 latitude sensitivity & 29.4 & 10.1 & 962 & 80 & 2 & 27.8 & 19.5 & 6.9 & 2194 \\
\hline V6 & V2 latitude sensitivity & 18.1 & 4.3 & 2590 & 161 & 81 & 26.4 & 17.0 & 7.2 & $2100^{*}$ \\
\hline V7 & V3 latitude sensitivity & 24.7 & 9.6 & 1034 & 81 & 6 & 27.8 & 19.1 & 6.7 & 2246 \\
\hline V8 & V4 latitude sensitivity & 17.8 & 3.5 & 2716 & 183 & 76 & 26.4 & 16.8 & 7.2 & $2094^{*}$ \\
\hline PO & 0-km plateau & 29.4 & 10.2 & 674 & 51 & 1 & 31.5 & 17.7 & 4.5 & 3380 \\
\hline P1 & 1-km plateau & 26.1 & 8.9 & 1084 & 86 & 10 & 29.0 & 18.1 & 6.3 & 2396 \\
\hline P2 & 2-km plateau & 23.2 & 8.0 & 1280 & 107 & 20 & 28.6 & 20.3 & 6.7 & 2260 \\
\hline P3 & 3-km plateau & 18.6 & 4.9 & 2346 & 172 & 47 & 26.9 & 18.2 & 6.6 & $2304^{*}$ \\
\hline P4 & 4-km plateau & 8.9 & -1.7 & 4718 & 196 & 177 & 27.0 & 19.7 & 7.6 & $1982^{*}$ \\
\hline
\end{tabular}

those with a valley floor at a height of $2 \mathrm{~km}$ bounded by mountains (V1, V3, V5, and V7), with either an open or closed eastern end. However, if the eastern end is closed (elevated) and the valley is deep ( $2-\mathrm{km}$ valley floor) as in scenarios V3 and V7, this leads to lower lapse rates where palms can potentially survive to slightly higher elevations ( $52 \mathrm{~m}$; Table 1), but eastern closure can make conditions in the valley highly susceptible to wind directions, resulting in slightly higher frequencies of potentially seedlingfatal frost days (Table 1).

Not all 2-km valley scenarios are plausible if model surface CMMT values are accepted. Model predictions independent of the Tirap proxy data (Table 1) show that all the more northerly valley scenarios (V1 to $\mathrm{V} 4$, valley located at $32.5^{\circ} \mathrm{N}$ ) yield a CMMT at the valley floor surface below the $5.2^{\circ} \mathrm{C}$ palm-survivable threshold. The more southerly location of the Lunpola valley $\left(30.0^{\circ} \mathrm{N}\right)$ with a $2-\mathrm{km}$ valley floor and a closed eastern end (scenario V7) yields the most benign conditions in terms of potential survivability to well above the valley floor, and the second fewest frost days (Table 1), but even then, survivable elevations do not exceed $2.3 \mathrm{~km}$. Newly dated plant fossil evidence suggests just such a highland in eastern Tibet in the Paleogene (27).

\section{DISCUSSION}

Our finding that the Lunpola paleovalley floor was at an elevation of no more than $2.3 \mathrm{~km}$ at $\sim 25 \mathrm{Ma}$ supports other low elevations derived from paleontological data (4-6) that have largely been overlooked or dismissed possibly because the surface height estimates were based on organisms less well environmentally constrained than palms, the inappropriate use of free-air lapse rates, and the loosely constrained adjustments for secular climate change. These approaches have led to surface height estimates ranging from $\sim 1 \mathrm{~km}$ (6) to $\sim 3.5 \mathrm{~km}$ (5), of which the $\sim 1-\mathrm{km}$ elevation is the most compatible with the outcome of our work.

Our result contrasts with an earlier pollen-derived surface height estimate of 3090 to $3290 \mathrm{~m}$ (5), but this difference can be explained by (i) downslope transport of pollen from taxa living on the bounding 

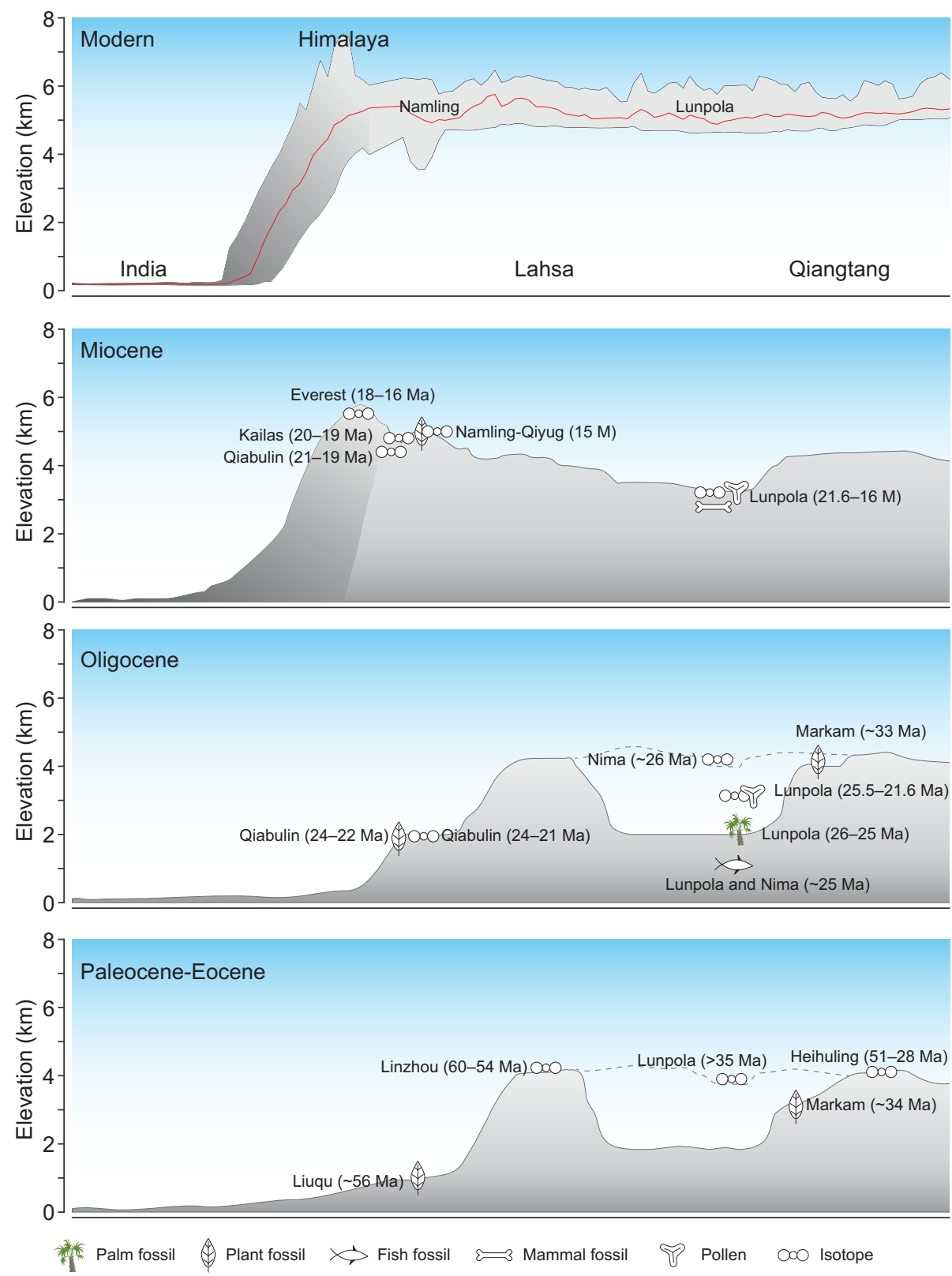

Fig. 3. Schematics representing south (left) to north (right) transects of the topography of the Lhasa and Qiangtang terranes, Tibet, and the Himalaya from the Paleocene to the present. Data sources: Paleocene-Eocene-Liuqu (22), Linzhou (12), Lunpola (3, 13), Heihuling (13), and Markam (27); Oligocene-Qiabulin (22, 42), Nima (6, 43), Lunpola (6, 43), and Markam (27); Miocene-Qiabulin (22, 42), Kailas (33), Everest (44), Namling (45), Qiyug (46), and Lunpola (4, 5). Note that Markam is located in eastern Tibet.

mountain slopes and (ii) lapse rate values. First, pollen representing montane conifers (Pinuspollenites, Piceapollenites, and Abiespollenites) and temperate broad-leaved species (Betulaepollenites, Quercoidites, and Ulmipollenites) occur within the Dingqing sediments admixed with typically subtropical evergreen pollen types (Castanopsispollenites and Meliaceoidites) (5) that presumably represent the valley floor paleovegetation. This mixing of high and low elevation taxa would falsely raise the height estimate for the valley floor by an indeterminate amount, but it does point to a pronounced topographic relief surrounding the Dingqing lake catchment. Second, the pollen study (5) used a regional free-air thermal lapse rate of $5.79^{\circ} \mathrm{C} / \mathrm{km}$ rather than the more appropriate $(18,19)$ within-valley terrestrial thermal lapse rates of $6.74^{\circ}$ to $6.9^{\circ} \mathrm{C} / \mathrm{km}$ derived and applied here (Table 1). This difference in lapse rates alone raises the pollen-based valley floor elevation estimate by 308 to $367 \mathrm{~m}$ compared with ours. If only the subtropical components of the pollen flora were used, in combination with a more appropriate terrestrial lapse rate, the estimated valley floor elevation would be much lower than $3 \mathrm{~km}$.

Free-air lapse rate and organismal tolerance issues apart, the estimate of $\sim 3 \mathrm{~km}$ derived from rhinocerid remains (4) may not be entirely incompatible with our result in that the deposits yielding the rhinocerid are dated as 18 to $16 \mathrm{Ma}$ and so are several million years 
younger than the palm-bearing layer. There is some evidence to suggest that regional uplift and drying began at $23.7 \mathrm{Ma}$ (11), although the rate and duration of this uplift require further investigation.

The valley system that we envisage is not the one produced by river incision, but a foreland basin-like depression resulting from the Mesozoic-Paleogene underthrusting of the Lhasa Terrane beneath the Qiangtang Terrane $(30,31)$ and, as such, must have extended along the length of the Bangong-Nujiang suture zone. Within this depression, a series of long-lasting interconnected deep and shallow lakes formed fed by inflowing streams and rivers $(11,30,32)$, but with little evidence of significant fluvial outflows. In the Nima Basin, also within the Bangong-Nujiang suture zone, the Late Oligocene sedimentological evidence for gravity flows reaching the lake shoreline indicates that relief was relatively steep and that the source terrane was within a few kilometers (30). Moreover, the Lunpola lake system seems to have been saline and hyper stratified (32), which indicates strongly a closed lake system, even though it had inflows from the south and the nearby freshwater Baingoin Basin (32). The existence of a large accommodation space and lack of significant drainage from the valley system is evidenced by the accumulation of $\sim 4000 \mathrm{~m}$ of Cenozoic sediments within several Bangong-Nujiang suture zone basins $(11,30,33,34)$. The documented lacustrine deposits of the Dingqing Formation alone are at least $1100 \mathrm{~m}$ thick based on borehole data (11).

The disparity between the isotope-derived paleoelevations and those based on fossils is likely due to downslope groundwater/stream transport of high-altitude meteoric isotope signatures. By contrast, leaves and animals have minimal capacity for downslope transport unscathed, and their environmental adaptations and tolerances reflect conditions close to their depositional location, i.e., surrounding the valley bottom lake margins. Together, the isotopic and biotic paleoaltimeters provide insights into the landscape diversity that are missed using only one form of elevation proxy.

Our discovery of S. tibetensis challenges the concept of a "protoTibetan Plateau," a term that suggests that the central part of Tibet was flat, if not as high as today $(3,7)$, or with moderate topographic lows of just 1 to $1.5 \mathrm{~km}$ below the adjacent Gangdese and Qiangtang highlands (5). Instead, we infer that a large valley system with a floor lower than $2.3 \mathrm{~km}$ AMSL existed in central Tibet as late as $25 \mathrm{Ma}$ and that the topography of Tibet during the Late Paleogene was far more complex than often envisaged (Fig. 3), a complexity that may be fundamental to the evolution of modern Asian biodiversity "hot spots" (35). The deep paleovalley system between the Gangdese and Qiangtang highlands now accommodates $\sim 4000 \mathrm{~m}$ of Cenozoic sediments (5) and suggests that a combination of valley fill and predominantly compressional tectonics raised the surface elevation after $\sim 25 \mathrm{Ma}$ to form the present high plateau.

\section{MATERIALS AND METHODS \\ Morphological description}

Family: Arecaceae Schultz Sch.

Subfamily: Coryphoideae Burnett

Genus: Sabalites G. Saporta emended Read and Hickey

Species: S. tibetensis T. Su et Z.K. Zhou sp. nov.

Holotype: XZDY2-0200 (designated here) (Fig. 2A)

Paratypes: XZDY1-0071, XZDY2-0201, XZDY2-0202, and

XZDY3-0001 (designated here) (fig. S1)

Repository: Palaeoecology Collections, XTBG, CAS

Type locality: Dayu Village, Lunpola Basin, central Tibetan Plateau Age: Late Oligocene (Chattian)
Etymology: The specific epithet "tibetensis" refers to the fossils being found in central Tibet.

Diagnosis: Leaves costapalmate. Costa/petiole thick at the base and gradually tapers toward apex, petiole robust, unarmed; longitudinal striations present on the petiole/costa. One pair of spine-like structures at the base of leaf blade. Leaf segment plicate, emerging from the costa an acute angle; fused at emerging point. Each leaf segment bears midveins; two order of veins present on either side of the mid-vein, transverse vein present either perpendicularly or oblique.

Description: The description is based on two specimens, which are part (Fig. 2A) and counterpart. Leaves are costapalmate (Fig. 2A and fig. $\mathrm{S1}$ ); maximum preserved length of the leaf blade is $\sim 310 \mathrm{~mm}$, and maximum preserved width of the leaf blade is $\sim 325 \mathrm{~mm}$; leaf blade slightly asymmetrical at base; petiole present, unarmed, maximum preserved length is $\sim 703 \mathrm{~mm}$ (including costa), maximum preserved width is $\sim 30 \mathrm{~mm}$, flattened, nearly same width from proximal to distal end; costa maximum length is $53 \mathrm{~mm}$, wide at base $(\sim 34 \mathrm{~mm})$ and gradually tapers distally; distinct spine-like structure present on the base of the costa, which is $~ 12 \mathrm{~mm}$ in length having a broad base and tapers gradually at the distal end; leaf segment plicate, fused only on the lower portion of the leaf blade; each leaf segment bears a mid-vein in the middle, numerous $2^{\circ}$ veins run parallel on either side of the mid-vein, $3^{\circ}$ veins present, running parallel in between $2^{\circ}$ veins, three to five in number; transverse veins present either perpendicularly or oblique to $3^{\circ}$ veins (Fig. 2, C and D).

Remarks: The characteristic features of the fossil leaf include palmate, plicate leaves with costa (costapalmate), and an unarmed long petiole. These characters suggest that the fossil leaves have affinities with the subfamily Coryphoideae in the Arecaceae. A large number of modern palm leaves were observed using herbaria at XTBG and the Kunming Institute of Botany, Kunming, the website of the Royal Botanic Garden, Kew, and Palmweb (www.palmweb.org).

As Read and Hickey (25) stated that "Since it is very difficult to identify specimens of modern palms accurately from their leaves alone, no attempt should be made to place fossil palm fragments in genera of modern palms unless unquestionably identifiable with them." Under these circumstances, the fossils were placed in the organ genus Sabalites G. Saporta proposed for costapalmate fossil leaves (36).

Numerous palm leaf fossils have been reported from various parts of the world, and it is not possible to compare all of them with the present fossil; however, we compared those that are most similar. In China, several costapalmate leaves have been described from Eocene sediments, such as Sabalites asymmetricus, Sabalites robustus, Sabalites tenuifolius, Sabalites szei, and Sabalites changchangensis (37), and Oligocene sediments, namely, Chuniophoenix slenderifolia, Livistona rotundifolia, and Trachycarpus formosa (38), based on some morphological features and preserved cuticular structures. In all the aforesaid fossils, the leaf blades are incomplete, the leaf segments are fused, and the preserved petioles are very short. These features are significantly different from those of the Tibetan fossils.

Similarly, a coryphoid palm leaf named Sabalites longirachis has been described from the early Campanian of Austria and Maastrichtian of the Pyrénées (23), and although it looks similar to our fossil, it has fused leaf segments, which is a major difference. Srivastava et al. (39) reported a similar type of coryphoid palm from the late MaastrichtianDanian sediments of Deccan Intertrappean beds of central India, but their fossil bears a long costa and fused leaf segments as distinct from our Tibetan fossil leaf. Therefore, in the absence of any similar leaves, we proposed the new species S. tibetensis T. Su et Z.K. Zhou sp. nov. 


\section{Climate model}

HadCM3L is a fully coupled atmosphere-ocean model consisting of 19 vertical levels in the atmosphere and 20 ocean depth levels and has an integrative vegetation model. We ran HadCM3L until ocean circulation equilibrated fully with no trend in the integrated ocean temperature. HadAM3, the atmospheric model of HadCM3L using the equilibrated sea surface temperatures (SSTs) from HadCM3L simulation, was used to perform the topography sensitivity studies. The HadCM3 family has seen extensive use as a principal model of the Inter-governmental Panel on Climate Change (IPCC) AR3-5 experiments. Crucially, the HadCM3 family shows skill in representing not only the mean climate state compared with observations globally (26) but also the monsoon climate of East Asia (40), where it outperforms most other models.

Simulations of the Chattian paleogeography use the Getech Plc. palaeogeographic reconstructions $\left(0.5^{\circ} \times 0.5^{\circ}\right.$ longitude $\times$ latitude $)$ (40) upscaled to the HadCM3L resolution (41). An ice sheet over Antarctica is also prescribed in these sets of simulations. Each simulation was run $>6000$ model years to achieve a steady state in the deep ocean as well as a radiative balance in the atmosphere.

\section{SUPPLEMENTARY MATERIALS}

Supplementary material for this article is available at http://advances.sciencemag.org/cgi/ content/full/5/3/eaav2189/DC1

Fig. S1. S. tibetensis T. Su et Z.K. Zhou sp. nov.

Fig. S2. Stratigraphy of the Dingqing Formation at Dayu, Lunpola Basin.

Fig. S3. Late Paleogene model elevations (meters) showing the different topographic scenarios for the QTP region.

Table S1. Fossil records of palms around the world.

Table S2. Morphological comparisons between fossils from Lunpola Basin and modern palm genera. Table S3. Climate ranges of 12 living genera that show the closest morphological similarity to S. tibetensis T. Su et Z.K. Zhou sp. nov.

\section{REFERENCES AND NOTES}

1. W. R. Boos, Z. Kuang, Dominant control of the South Asian monsoon by orographic insulation versus plateau heating. Nature 463, 218-222 (2010).

2. X. Liu, B. Dong, Influence of the Tibetan Plateau uplift on the Asian monsoon-arid environment evolution. Chin. Sci. Bull. 58, 4277-4291 (2013).

3. D. B. Rowley, B. S. Currie, Palaeo-altimetry of the late Eocene to Miocene Lunpola basin, central Tibet. Nature 439, 677-681 (2006).

4. T. Deng, S.-Q. Wang, G.-P. Xie, Q. Li, S.-K. Hou, B.-Y. Sun, A mammalian fossil from the Dingqing Formation in the Lunpola Basin, northern Tibet, and its relevance to age and paleo-altimetry. Chin. Sci. Bull. 56, 2873-2880 (2011).

5. J. Sun, Q. Xu, W. Liu, Z. Zhang, L. Xue, P. Zhao, Palynological evidence for the latest Oligocene-early Miocene paleoelevation estimate in the Lunpola Basin, central Tibet. Palaeogeogr. Palaeoclimatol. Palaeoecol. 399, 21-30 (2014).

6. F. Wu, D. Miao, M.-m. Chang, G. Shi, N. Wang, Fossil climbing perch and associated plant megafossils indicate a warm and wet central Tibet during the late Oligocene. Sci. Rep. 7, 878 (2017).

7. P. J. Polissar, K. H. Freeman, D. B. Rowley, F. A. Mclnerney, B. S. Currie, Paleoaltimetry of the Tibetan Plateau from $D / H$ ratios of lipid biomarkers. Earth Planet. Sci. Lett. 287, 64-76 (2009).

8. S.-S. Chen, R.-D. Shi, X.-H. Gong, D.-L. Liu, Q.-S. Huang, G.-D. Yi, K. Wu, H.-B. Zou, A syn-collisional model for Early Cretaceous magmatism in the northern and central Lhasa subterranes. Gondwana Res. 41, 93-109 (2017).

9. D. Liu, R. Shi, L. Ding, Q. Huang, X. Zhang, Y. Yue, L. Zhang, Zircon U-Pb age and Hf isotopic compositions of Mesozoic granitoids in southern Qiangtang, Tibet: Implications for the subduction of the Bangong-Nujiang Tethyan Ocean. Gondwana Res. 41, 157-172 (2017).

10. H. He, J. Sun, Q. Li, R. Zhu, New age determination of the Cenozoic Lunpola basin, central Tibet. Geol. Mag. 149, 141-145 (2012).

11. P. Ma, C. Wang, J. Meng, C. Ma, X. Zhao, Y. Li, M. Wang, Late Oligocene-early Miocene evolution of the Lunpola Basin, central Tibetan Plateau, evidences from successive lacustrine records. Gondwana Res. 48, 224-236 (2017).
12. L. Ding, Q. Xu, Y. Yue, H. Wang, F. Cai, S. Li, The Andean-type Gangdese Mountains: Paleoelevation record from the Paleocene-Eocene Linzhou Basin. Earth Planet. Sci. Lett. 392, 250-264 (2014).

13. Q. Xu, L. Ding, L. Zhang, F. Cai, Q. Lai, D. Yang, J. Liu-Zeng, Paleogene high elevations in the Qiangtang Terrane, central Tibetan Plateau. Earth Planet. Sci. Lett. 362, 31-42 (2013).

14. M. T. Hren, B. Brookhagen, P. M. Blisniuk, A. L. Booth, C. P. Chamerlain, $\delta^{18} O$ and $\delta D$ of streamwaters across the Himalaya and Tibetan Plateau: Implications for moisture sources and paleoelevation reconstructions. Earth Planet. Sci. Lett. 288, 20-32 (2009).

15. J. Bershaw, S. M. Penny, C. N. Garzione, Stable isotopes of modern water across the Himalaya and eastern Tibetan Plateau: Implications for estimates of paleoelevation and paleoclimate. J. Geophys. Res. 117, D02110 (2012).

16. J. Gelewsky, Orographic precipitation isotopic ratios in stratified atmospheric flows: Implications for paleoelevation studies. Geology 37, 791-794 (2009).

17. A. Mulch, C. P. Chamberlain, in Mountains, Climate and Biodiversity, C. Hoorn, A. Perrigo, A. Antonelli, Eds. (Wiley-Blackwell, 2018), chap. 6, pp. 81-93.

18. H. W. Meyer, A review of paleotemperature-lapse rate methods for estimating paleoelevation from fossil floras. Rev. Miner. Geochem. 66, 155-171 (2007).

19. R. A. Spicer, in Mountains, Climate and Biodiversity, C. Hoorn, A. Perrigo, A. Antonelli, Eds. (Wiley-Blackwell, 2018), chap. 7, pp. 96-109.

20. R. A. Spicer, J. A. Wolfe, Plant taphonomy of late Holocene deposits in Trinity (Clair Engle) Lake, northern California. Paleobiology 13, 227-245 (1987).

21. T. Reichgelt, C. K. West, D. R. Greenwood, The relation between global palm distribution and climate. Sci. Rep. 8, 4721 (2018).

22. L. Ding, R. A. Spicer, J. Yang, Q. Xu, F. Cai, S. Li, Q. Lai, H. Wang, T. E. V. Spicer, Y. Yue, A. Shukla, G. Srivastava, M. A. Khan, S. Bera, R. Mehrotra, Quantifying the rise of the Himalaya orogen and implications for the South Asian monsoon. Geology 45, 215-218 (2017).

23. J. B. Marmi, B. Gomez, C. Martín-Closas, S. Villalba-Breva, A reconstruction of the fossil palm Sabalites longirhachis (Unger) J. Kvaček et Herman from the Maastrichtian of Pyrenees. Rev. Palaeobot. Palynol. 163, 73-83 (2010).

24. S. B. Archibald, G. E. Morse, D. R. Greenwood, R. W. Mathewes, Fossil palm beetles refine upland winter temperatures in the Early Eocene Climatic Optimum. Proc. Natl. Acad. Sci. U.S.A. 111, 8095-8100 (2014).

25. R. W. Read, L. J. Hickey, A revised classification of fossil palm and palm-like leaves. Taxon 21, 129-137 (1972).

26. P. J. Valdes, E. Armstrong, M. P. S. Badger, C. D. Bradshaw, F. Bragg, M. Crucifix, T. Davies-Barnard, J. J. Day, A. Farnsworth, P. O. Hopcroft, A. T. Kennedy, N. S. Lord, D. J. Lunt, A. Marzocchi, L. M. Parry, W. H. G. Roberts, E. J. Stone, G. J. L. Tourte, J. H. T. Williams, The BRIDGE HadCM3 family of climate models: HadCM3@Bristol v1.0. Geosci. Model Dev. 10, 3715-3743 (2017).

27. T. Su, R. A. Spicer, S.-H. Li, H. Xu, J. Huang, S. Sherlock, Y.-J. Huang, S.-F. Li, L. Wang, L.-B. Jia, W.-Y.-D. Deng, J. Liu, C.-L. Deng, S.-T. Zhang, P. J. Valdes, Z.-K. Zhou, Uplift, climate and biotic changes at the Eocene-Oligocene transition in south-eastern Tibet. Natl. Sci. Rev., nwy062 (2018).

28. G. L. Foster, D. L. Royer, D. J. Lunt, Future climate forcing potentially without precedent in the last 420 million years. Nat. Commun. 8, 14845 (2017).

29. G. Srivastava, R. A. Spicer, T. E. V. Spicer, J. Yang, M. Kumar, R. Mehrotra, N. Mehrotra, Megaflora and palaeoclimate of a Late Oligocene tropical delta, Makum Coalfield, Assam: Evidence for the early development of the South Asia Monsoon. Palaeogeogr. Palaeoclimatol. Palaeoecol. 342-343, 130-142 (2012).

30. P. Kapp, P. G. DeCelles, G. E. Gehrels, M. Heizler, L. Ding, Geological records of the LhasaQiangtang and Indo-Asian collisions in the Nima area of central Tibet. Geol. Soc. Am. Bull. 119, 917-933 (2007).

31. P. Kapp, M. A. Murphy, A. Yin, T. M. Harrison, L. Ding, J. Guo, Mesozoic and Cenozoic tectonic evolution of the Shiquanhe area of western Tibet. Tectonics 22, 1029 (2003).

32. P. Ma, L. Wang, C. Wang, X. Wu, Y. Wei, Organic-matter accumulation of the lacustrine Lunpola oil shale, central Tibetan Plateau: Controlled by the paleoclimate, provenance, and drainage system. Int. J. Coal Geol. 147-148, 58-70 (2015).

33. P. G. DeCelles, I. S. Castañeda, B. Carrapa, J. Liu, J. Quade, R. Leary, L. Zhang, OligoceneMiocene great lakes in the India-Asia collision zone. Basin Res. 30, 228-247 (2018).

34. B.-W. Du, F.-W. Tan, M. Chen, Sedimentary features and petroleum geology of the Lunpola Basin, Xizang. Sediment. Geol. Tethyan Geol. 24, 46-54 (2004).

35. R. A. Spicer, Tibet, the Himalaya, Asian monsoons and biodiversity - In what ways are they related? Plant Divers. 39, 233-244 (2017).

36. G. Saporta, Études sur la vegetation du sud-est de la France a lépoque tertiare. Ann. Sci. Nat. 5, 5-152 (1865).

37. W. Zhou, X. Liu, Q. Xu, K. Huang, J. Jin, New coryphoid fossil palm leaves (Arecaceae: Coryphoideae) from the Eocene Changchang Basin of Hainan Island, South China. Sci. China Earth Sci. 56, 1493-1501 (2013).

38. Q.-J. Wang, F.-J. Ma, J.-L. Dong, Y. Yang, P.-H. Jin, B.-N. Sun, Coryphoid palms from the Oligocene of China and their biogeographical implications. C. R. Palevol 14, 263-279 (2015). 
39. R. Srivastava, G. Srivastava, D. L. Dilcher, Coryphoid palm leaf fossils from the Maastrichtian-Danian of Central India with remarks on phytogeography of the Coryphoideae (Arecaceae). PLOS ONE 9, e111738 (2014).

40. K. R. Sperber, H. Annamalai, I.-S. Kang, A. Kitoh, A. Moise, A. Turner, B. Wang, T. Zhou, The Asian summer monsoon: An intercomparison of CMIP5 vs. CMIP3 simulations of the late 20th century. Clim. Dyn. 41, 2711-2744 (2013).

41. D. J. Lunt, A. Farnsworth, C. Loptson, G. L. Foster, P. Markwick, C. L. O’Brien, R. D. Pancost, S. A. Robinson, N. Wrobel, Palaeogeographic controls on climate and proxy interpretation. Clim. Past 12, 1181-1198 (2016).

42. Q. Xu, L. Ding, R. A. Spicer, X. Liu, S. Li, H. Wang, Stable isotopes reveal southward growth of the Himalayan-Tibetan Plateau since the Paleocene. Gondwana Res. 54, 50-61 (2018).

43. N. Wang, F. Wu, New Oligocene cyprinid in the central Tibetan Plateau documents the pre-uplift tropical lowlands. Ichthyol. Res. 62, 274-285 (2015).

44. A. Gébelin, A. Mulch, C. Teyssier, M. J. Jessup, R. D. Law, M. Brunel, The miocene elevation of Mount Everest. Geology 41, 799-802 (2013).

45. M. A. Khan, R. A. Spicer, S. Bera, R. Ghosh, J. Yang, T. E. V. Spicer, S.-X. Guo, T. Su, F. Jacques, P. J. Grote, Miocene to Pleistocene floras and climate of the Eastern Himalayan Siwaliks, and new palaeoelevation estimates for the Namling-Oiyug Basin, Tibet. Glob. Planet. Chang. 113, 1-10 (2014).

46. B. S. Currie, P. J. Polissar, D. B. Rowley, M. Ingalls, S. Li, G. Olack, K. H. Freeman, Multiproxy palaeoaltimetry of the late Oligocene-Pliocene Oiyug Basin, Southern Tibet. Am. J. Sci. 316, 401-436 (2016).

47. J. Yang, R. A. Spicer, T. E. V. Spicer, C.-S. Li, 'CLAMP Online': A new web-based palaeoclimate tool and its application to the terrestrial Paleogene and Neogene of North America. Palaeobiodivers. Palaeoenv. 91, 163-183 (2011).

Acknowledgments: We thank the organizers of Second Tibetan Plateau Scientific Expedition (STEP) for financial and logistic support during the field work; colleagues from the Institute of Vertebrate Paleontology and Paleoanthropology, Chinese Academy of Sciences (CAS) for assistance during fossil collection; the Public Technology Service Center, Xishuangbanna Tropical Botanical (XTBG), CAS for imaging; and G. Dupont-Nivet and anonymous reviewers for the many constructive suggestions. Funding: This work was supported by the Strategic Priority Research Program of CAS [nos. XDA20070301 (to Z.-K.Z.) and XDA20070203 (to T.D.)] the National Natural Science Foundation of China (NSFC) [nos. 31470325 (to T.S.), 31590823 (to Z.-K.Z. and Y.-J.H.), 41430102 (to T.D.), and 41872006 (to F.-X.W.)]; the NSFC-NERC (Natural Environment Research Council of the United Kingdom) joint research program [nos. 41661134049 (to T.S.) and NE/P013805/1 (to P.J.V.)]; the XTBG International Fellowship for Visiting Scientists to R.A.S.; the National Key R\&D Program of China (no. 2017 YFC0505200 to Y.-W.X.); the Key Research Program of Frontier Sciences, CAS (no. QYZDB-SSW-SMC016 to T.S.); the Youth Innovation Promotion Association, CAS [nos. 2017439 (to T.S.) and 2017103 (to F.-X.W.)] and the CAS 135 program (no. 2017XTBG-F01 to T.S.). Author contributions: T.S., F.-X.W., and Z.-K.Z. designed the research plan. T.S., J.H., F.-X.W., J.L., Y.-W.X., W.-Y.-D.D., H.T., C.-L.X., F.Z., T.D., and Z.-K.Z. conducted the field work. T.S., A.F., P.J.V., and R.A.S. performed the analyses. T.S A.F., R.A.S., G.S., and Z.-K.Z. wrote the manuscript. All authors discussed and commented on the manuscript. Competing interests: The authors declare that they have no competing interests. Data and materials availability: All data needed to evaluate the conclusions in the paper are present in the paper and/or the Supplementary Materials. Additional data related to this paper may be requested from the authors. Correspondence and requests for materials should be addressed to T.S. (sutao@xtbg.org.cn) and Z.-K.Z. (zhouzk@xtbg.ac.cn).

Submitted 25 August 2018

Accepted 25 January 2019

Published 6 March 2019

$10.1126 /$ sciadv.aav2189

Citation: T. Su, A. Farnsworth, R. A. Spicer, J. Huang, F.-X. Wu, J. Liu, S.-F. Li, Y.-W. Xing, Y.-J. Huang, W.-Y.-D. Deng, H. Tang, C.-L. Xu, F. Zhao, G. Srivastava, P. J. Valdes, T. Deng, Z.-K. Zhou, No high Tibetan Plateau until the Neogene. Sci. Adv. 5, eaav2189 (2019). 